\title{
Influence of phytoplankton concentration and wave exposure on the ecophysiology of Mytilus californianus
}

\author{
Elizabeth P. Dahlhoff*, Bruce A. Menge \\ Oregon State University, Department of Zoology, Corvallis, Oregon 97331-2914, USA
}

\begin{abstract}
The relationship between nearshore food availability and physiological state of the suspension-feeding mussel Mytilus californianus was examined along a wave-exposure gradient at 2 rocky intertidal sites on the Oregon coast, USA, differing in nearshore concentrations of phytoplankton. The RNA:DNA ratio (an indirect measure of protein synthetic capacity) of adductor muscle was used as an indicator of dietary status and growth. The activities of 2 metabolic enzymes, citrate synthase (CS) and malate dehydrogenase (MDH), were measured for gill (CS) and adductor (MDH) as indicators of metabolic activity. Mussels were sampled at wave-exposed and wave-protected areas at Strawberry Hill (SH), a site with relatively high phytoplankton concentrations, and Boiler Bay (BB), a site with relatively low phytoplankton concentrations. Individuals at wave-exposed areas at both $\mathrm{SH}$ and $\mathrm{BB}$ had higher RNA:DNA ratios in spring and summer than those at wave-protected areas. RNA:DNA ratios in spring and summer were higher at SH than at BB, and these differences were especially pronounced following coastal upwelling events. Increases in RNA:DNA ratio during phytoplankton blooms after upwelling suggest that mussels respond rapidly to short-term changes in nearshore oceanographic conditions. Both CS and MDH activities were higher at SH than at BB many times throughout the year, suggesting metabolic activity was higher overall for $\mathrm{SH}$ mussels. Reciprocal transplant experiments were performed to evaluate the degree of physiological plasticity in relation to site- and exposurerelated factors (e.g. phytoplankton concentration, heat and/or desiccation stress, wave forces) Between-site transplants were done between wave-exposed areas at $\mathrm{SH}$ and $\mathrm{BB}$; within-site transplants were done between areas of different wave-exposure at each of the 2 sites. RNA:DNA ratios of transplanted mussels converged on those of the site or area to which they were transplanted, suggesting that mussel physiology is highly plastic in response to site and area-related variations in environmental factors. The strong apparent response of mussels to variations in phytoplankton concentration suggests that physiological indices may be useful tools in assessing the magnitude of 'bottom-up' effects in rocky intertidal communities.
\end{abstract}

KEY WORDS: Mytilus californianus - Rocky intertidal $\cdot$ Ecophysiology $\cdot$ Food availability

\section{INTRODUCTION}

Organisms living in rocky intertidal regions experience spatial and temporal variability in environmental conditions due to steep gradients in wave impact, food availability, temperature, and desiccation (Paine 1977. Newell 1979, Menge \& Farrell 1989). Biochemical and

\footnotetext{
- Present address: Department of Biology, Sonoma State University, $1801 \mathrm{E}$. Cotati Ave, Rohnert Park, California 94928, USA.E-mail: dahlhoff@sonoma.edu
}

physiological processes of intertidal organisms can vary over a wide range of values in response to this environmental variation, and organismal performance (growth, reproduction, mobility, etc.) may therefore be modified in response to environmental conditions (Hawkins \& Bayne 1984, Stickle et al. 1985, Menge \& Sutherland 1987, Stickle \& Bayne 1987, van Erkom Schurink \& Griffiths 1992, Hofmann \& Somero 1995). These physiological adjustments may have profound effects on the distribution and abundance of a single species, as well as on that species' interactions with 
other species in its habitat, and therefore on the entire structure of a given rocky intertidal community. Because key species interactions often vary significantly along these same environmental gradients (Connell 1961a, b, Dayton 1971, Paine 1974, Lubchenco 1978 Menge 1978a, b, 1991, Menge \& Sutherland 1987 Menge et al. 1994), it is likely that physiological mechanisms underlie environmentally induced variation in community structure. To gain a more detailed understanding of the link between one environmental variable, the availability of food, and the physiological ecology of the rocky intertidal region, we examined biochemical indices of nutritional status in an ecologically important species of marine invertebrate, the suspension-feeding mussel Mytilus californianus.

Variation in food and nutrient availability has profound effects on the physiology of intertidal suspension feeders (Bayne \& Widdows 1978. Hawkins \& Bayne 1984. Stickle \& Bayne 1987, Bertness et al, 1991, van Erkom Schurink \& Griffiths 1992, Bayne et al. 1993, Kreeger et al. 1995). Suspension-feeding invertebrates living in the rocky intertidal region may experience variation in food quality and quantity, nutrients, and in feeding opportunities within and between sites due to strong environmental gradients in phytoplankton productivity (see below), quality of food, wave exposure, relief of substratum, and tidal level (Navarro \& Winter 1982, Bayne \& Hawkins 1990. Hawkins \& Bayne 1992). Suspension-feeding animals living in wave-exposed areas may have more or longer feeding opportunities than do individuals in wave-protected areas because of greater water flow at wave-exposed sites. Although mussels may compensate for lower feeding time at wave-protected sites with higher feeding efficiency (Kreeger et al. 1991), thermal and desiccation stress at wave-protected areas may suppress metabolism (Roberts et al. in press).

Variation in the availability of food to suspensionfeeding invertebrates resulting from variation in nearshore phytoplankton concentration or feeding time may influence the structure of rocky intertidal communities (Menge \& Olson 1990, Menge et al. 1995, 1996). Although the importance of bottom-up effects (so named because regulating processes originate at the base of the food web) on community structure has long been debated (e.g Oksanen et al. 1981, Fretwell 1987. Carpenter 1988, McQueen et al. 1989), recent studies along the Oregon coast suggest that rocky intertidal community structure and regulation may vary with nearshore phytoplankton concentration and primary productivity (hereafter PP) (Menge 1992, Menge et al. 1994, 1995). Because energy input of nearshore PP into intertidal communities occurs through suspensionfeeding invertebrates (primarily mussels and barnacles), examination of the effects of variation in PP and feeding opportunity on the dietary physiology of suspension feeders is a logical step to elucidating the mechanisms by which variation in PP input affects rocky intertidal community structure

We examined mussels living at 2 rocky intertidal habitats on the Oregon coast, Strawberry Hill (hereafter SH: $44^{\circ} 15^{\prime} \mathrm{N}, 124^{\circ} 07^{\prime} \mathrm{W}$ ) and Boiler Bay (hereafter $\mathrm{BB}: 44^{\circ} 40^{\prime} \mathrm{N}, 124^{\circ} 03^{\prime} \mathrm{W}$ ). Patterns of species distribution and abundance differ strikingly between these 2 sites (Menge et al. 1994). At BB, macrophyte abundance in the low zone is relatively high while abundance of sessile suspension feeders (e.g mussels and barnacles), and invertebrate herbivores and predators (e.g. seastars and whelks) is relatively low. Conversely, at $\mathrm{SH}$, macrophyte abundance is relatively low while abundance of suspension-feeding invertebrates, invertebrate herbivores and predators is relatively high.

Phytoplankton abundance and productivity, indexed by chlorophyll a (hereafter chl a) and ${ }^{14} \mathrm{C}$ respectively, were consistently higher at SH than at BB (Menge et al. 1995, 1996). From February to June in 1993 and 1994, for example, monthly water samples taken showed that the average concentration of chl a at $\mathrm{SH}$ was $3.37 \pm 2.00 \mu \mathrm{g} \mathrm{l}^{-1}$ and $5.00 \pm 1.22 \mu \mathrm{g} \mathrm{l}^{-1}$ respectively, whereas during those same times, chI a at BB was $0.55 \pm 0.20 \mu \mathrm{g} \mathrm{l}^{-1}$ and $1.87 \pm 0.90 \mathrm{\mu g} \mathrm{l}^{-1}$. These patterns are even more pronounced during the summer after periods of coastal upwelling, when chl a concentrations at $\mathrm{SH}$ are up to 5 -fold greater than those at BB. For example, on 2 July 1993, chl a concentration was $50 \pm 4.8 \mu \mathrm{g} \mathrm{l}^{-1}$ at S.H and $11.0 \pm 2.9 \mu \mathrm{g} \mathrm{l}^{-1}$ at BB; on 16 July 1.994, chl a concentrations were $29 \pm 3.5 \mu \mathrm{g} \mathrm{l}^{-1}$ at $\mathrm{SH}$ and $7.2 \pm 5.0 \mu \mathrm{g} \mathrm{I}^{-1}$ at BB (Menge et al. 1995). These data suggest that suspension feeders living at $\mathrm{SH}$ have more food available in most months than do suspension feeders living at BB, and that this difference is extreme during and after coastal upwelling.

Adjustments in rates of physiological processes may be necessary to bring metabolic demands of organisms into alignment with available energy supplies (Hawkins \& Bayne 1984, Hochachka \& Somero 1984, van Erkom Schurink \& Griffiths 1992, Bayne et al. 1993). Therefore, variation in food availability may be reflected in variation in metabolic activity. Previous studies of marine organisms have shown the potential for using biochemical data to develop links between metabolic activity and food availability. For example, depriving some organisms of food, or significantly reducing their abilities to feed, results in a concomitant decrease in the activities of metabolic enzymes relative to fed controls (Sullivan \& Somero 1983, Yang \& Somero 1993, Stillman et al. 1994, Dahlhoff \& Menge 1996). The activities of metabolic enzymes may therefore be considered an approximate index of dietary- 
dependent changes in metabolic activity in situ. Another physiological index that is sensitive to changes in dietary status of many organisms is the RNA:DNA ratio, as it reflects the protein synthetic capacity of a given tissue at any time (Buckley 1984, Wright \& Hetzel 1985, Martinez et al. 1992, Foster et al. 1993, Stillman et al. 1994). In this study, the activities of metabolic enzymes (citrate synthase and malate dehydrogenase) and RNA:DNA ratios were used to monitor changes in metabolic activity of mussels exposed to seasonal and site-related differences in food and nutrient availability at $\mathrm{SH}$ and $\mathrm{BB}$.

\section{MATERIALS AND METHODS}

Study organism. Mytilus californianus was selected for study as it is a major component of rocky intertidal communities along much of the west coast of North America and is abundant at BB and SH. $M$. californianus inhabits the mid-intertidal zone on exposed coasts from southern Baja California to the Aleutian Islands. It is a major competitor for space along waveswept rocky shores, is a favored prey of certain predators, particularly the seastar Pisaster ochraceus, and is thus a central species in community dynamics (Paine $1966,1974,1984)$. Furthermore, the distribution, abundance, and relationships between mussels and other species at $\mathrm{SH}$ and $\mathrm{BB}$ have been well-studied (Menge 1992, Menge et al. 1994, Navarrete \& Menge 1996).

Mussel collection. Starting in May 1993, mussels were collected every $90 \mathrm{~d}$ at wave-exposed and waveprotected areas at SH and BB. Sampling during July (1993 and 1994) was conducted 5 to $10 \mathrm{~d}$ after the peak of the large, upwelling-induced increases in chl a (Menge et al. 1995; see also 'Introduction'). Ten individuals for each site-exposure treatment were collected at randomly determined locations along a $10 \mathrm{~m}$ transect line laid parallel to the shore at each waveexposed and wave-protected area. Individuals were placed in a cooler on ice and brought to the laboratory, where they were immediately dissected, weighed, and frozen on dry ice. Dissected tissues were stored at $-70^{\circ} \mathrm{C}$ until biochemical analyses were conducted.

Upwelling measurements. Water samples were collected during and after coastal upwelling in June and July 1994. Upwelling was evidenced by strong northwest winds, as well as a decrease in nearshore water temperature. The concentration of chl a in nearshore water was determined fluorometrically (Menge et al. 1995). Water samples were collected directly at each site and were processed within $14 \mathrm{~h}$ of sampling. Mussels were collected from the exact location of water sampling before, during and after upwelling. Individuals were placed in a cooler on ice and brought to the laboratory, where they were immediately dissected, weighed, and frozen on dry ice. Dissected tissues were stored at $-70^{\circ} \mathrm{C}$ until analyzed.

RNA:DNA ratios. Concentrations of RNA and DNA in adductor muscle were determined by ethidium bromide fluorescence following the method of Bentle et al. (1981) as modified by Stillman et al. (1994). Tissues were thawed on ice, weighed and homogenized in 20 to 30 volumes $2 \mathrm{M} \mathrm{NaCl}$ (dilution depended on tissue type) with a hand-driven glass homogenizer (Kontes Duall, Vineland, NJ, USA). From each sample $50 \mu \mathrm{l}$ was incubated in $1.5 \mathrm{ml}$ of $0.005 \mathrm{mg} \mathrm{m}^{-1}$ ethidium bromide and $0.10 \mathrm{mg} \mathrm{ml}^{-1}$ proteinase $\mathrm{K}$ at $37^{\circ} \mathrm{C}$ for $90 \mathrm{~min}$. After incubation, $0.5 \mathrm{ml}$ buffer $(80 \mathrm{mM}$ Tris- $\mathrm{Cl}, \mathrm{pH} 7.5$ at $20^{\circ} \mathrm{C}$ ) was added, and fluorescence was recorded at $365 \mathrm{~nm}$ excitation and $590 \mathrm{~nm}$ emission using a PerkinElmer LS-5B luminescence spectrofluorometer. RNA and DNA concentrations of tissues were estimated from a standard curve calculated by measuring the fluorescence of known quantities of RNA and DNA (Sigma calf thymus DNA, 1 to $4 \mu \mathrm{g}$; Sigma calf liver RNA, type IV, 2 to $8 \mu \mathrm{g}$ ).

Citrate synthase and malate dehydrogenase activities. Tissues were thawed on ice, weighed and immediately homogenized in 10 volumes ice-cold $50 \mathrm{mM}$ potassium phosphate buffer $\left(\mathrm{pH} 6.8\right.$ at $\left.20^{\circ} \mathrm{C}\right)$ with a glass homogenizer, as described above. The homogenate was centrifuged at $4^{\circ} \mathrm{C}$ in a fixed rotor microfuge for $5 \mathrm{~min}$ at $14000 \times \mathrm{g}$, and the supernatant was collected and used for enzymatic activity determinations. Enzymes were assayed spectrophotometrically following the methods of Yang \& Somero (1993) and Stillman et al. (1994). Enzymatic activities are reported in International Units per gram wet mass ( $\mathrm{IU} \mathrm{g}^{-1}$ ).

Mussel transplants. Mussels were collected in May 1994 from wave-exposed and wave-protected areas at both $\mathrm{SH}$ and $\mathrm{BB}$ and transplanted using the methods of Menge et al. (1994). Mussels were collected at comparable tidal heights at both $\mathrm{SH}$ and $\mathrm{BB}$ and were reciprocally transplanted across sites and wave exposures [n (number of transplanted clumps) $=4$ ]. To control for transplant effects, mussels were also transplanted within their site of origin. A single set of transplants $(n=4)$ served as the control for both site and waveexposure manipulations.

Clumps of 20 mussels each were held against the rock with cages of Vexar plastic mesh to allow the mussels to reattach byssal threads to the rock. After $14 \mathrm{~d}$, most of the mussels had reattached and cages were loosened to free the mussels from the restraint of the mesh. Cages were left in place over the mussel clumps in order to exclude Pisaster ochraceus. Until October 1994, 3 individuals were removed from each cage every $30 \mathrm{~d}$. Specimens were handled for biochemical analysis as described previously. 
Statistical analyses. One-way, univariate and multivariate ANOVA were used to compare seasonal and site-related variation of RNA:DNA ratios and enzymatic activities of mussels. Univariate and multivariate repeated-measures ANOVA and 1-way ANOVA were used to analyze data from mussel transplant studies. Statistical analyses were conducted on non-transformed data using SYSTAT (Release 5.0 for Macintosh; Wilkinson 1990). Assumptions of normality, independence of error terms, and homogeneity of variances were evaluated and found to fit the assumptions of the models used.

\section{RESULTS}

\section{Biochemical variation in natural populations}

RNA:DNA ratio: differences between sites and exposures

In field-collected individuals, RNA:DNA ratios for adductor muscle of mussels from wave-exposed areas at SH were significantly higher than RNA:DNA ratios of mussels from BB in July of 1993 and 1994 (compare circle data points for July in Fig. $1 A_{1}, B_{i} p<0.050$, 1-way ANOVA; probabilities adjusted with Bonferroni approximation for multiple comparisons). RNA:DNA ratios were also significantly greater at the $\mathrm{SH}$ waveprotected area than at the BB wave-protected area in July of 1993 and 1994 (compare triangle data points for July in Fig. 1A, B; p < 0.050). With the exception of higher RNA:DNA ratios at the BB wave-exposed area in autumn 1993 ( $p<0.050)$, RNA:DNA ratios of Mytilus californianus did not differ between $\mathrm{SH}$ and $\mathrm{BB}$ in other seasons; that is, differences between sites were time-dependent (Site $\times$ Time interaction was significant; Table 1). The July collections that resulted in the significant differences between $\mathrm{SH}$ and $\mathrm{BB}$ were made

Table 1 Three-way ANOVA on the effect of site, exposure, and time on the RNA:DNA ratio of Mytilus californianus. Site: Strawberry Hill and Boiler Bay; exposure: wave exposed, wave protected; time: every $90 \mathrm{~d}$ from May 1993 to July 1994. Site, exposure, and time were treated as fixed variables. ns: $p>0.050$

\begin{tabular}{|lccccc}
\hline Source of variation & df & MS & $F$ & $p$ \\
\hline Site & 1 & 43.15 & 19.79 & $<0.0005$ \\
Exposure & 1 & 71.51 & 32.80 & $<0.0005$ \\
Time & 5 & 24.89 & 11.41 & $<0.0005$ \\
Site $\times$ Exposure & 1 & 1.468 & 0.673 & ns \\
Site $\times$ Time & 5 & 11.60 & 5.322 & $<0.0005$ \\
Exposure $\times$ Time & 5 & 11.81 & 5.417 & $<0.0005$ \\
Site $\times$ Exposure $\times$ Time & 5 & 0.343 & 0.158 & $n s$ \\
Error & 202 & 2.180 & & \\
\hline
\end{tabular}

A: Strawberry Hill
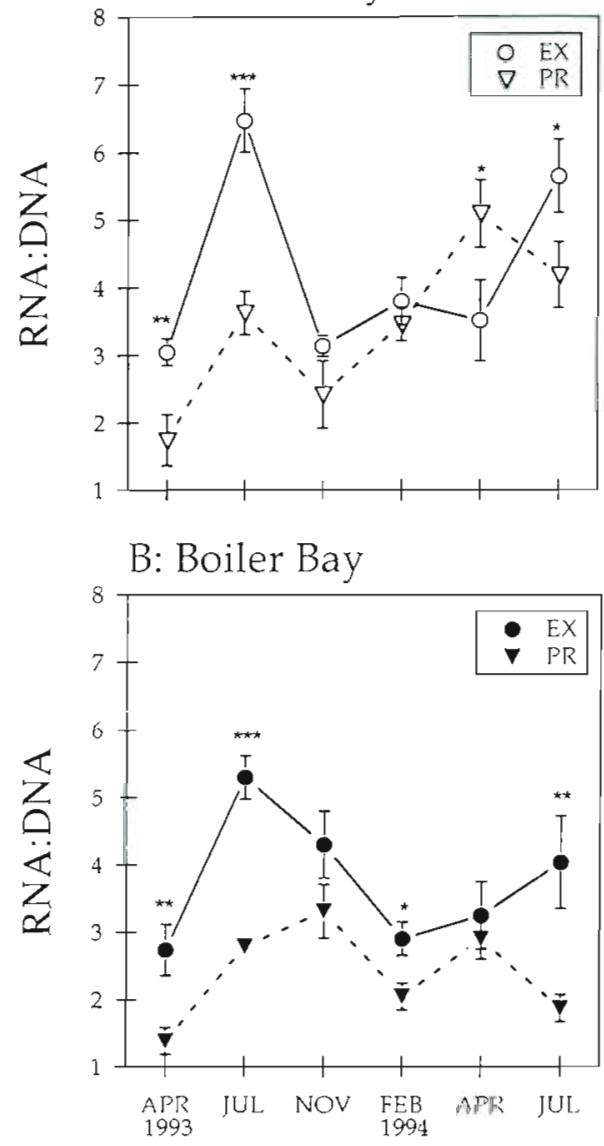

Fig. 1 Mytilus californianus Changes in protein synthetic capacity, as indexed by RNA:DNA ratio, of mussels from wave-exposed (EX) and wave-protected (PR) areas at (A) Strawberry Hill and (B) Boiler Bay (Oregon, USA). Data points are means $( \pm 1 \mathrm{SE})$ of 10 individuals that were collected $90 \mathrm{~d}$ apart. Asterisks indicate significance of comparison between exposures by date $(" p<0.05, \cdots p<0.01, \cdots p<0.001)$. Additional statistical analysis in Table 1.

5 to $10 \mathrm{~d}$ following coastal upwelling events that occurred in late June to early August (Menge et al. 1995; Fig 2).

RNA:DNA ratios of Mytilus californianus also differed between wave exposures independent of site (Fig. 1A, $B$; Site $\times$ Exposure interaction was not significant; Table 1). At $\mathrm{SH}$, RNA:DNA ratio was greater at waveexposed than at wave-protected areas in April and July 1993 and 1994; values in other seasons were not different (Fig. 1 A; p-values for 1-way ANOVA shown). Similarly, RNA:DNA ratios were greater at wave-exposed than at wave-protected areas at $B B$ in April 


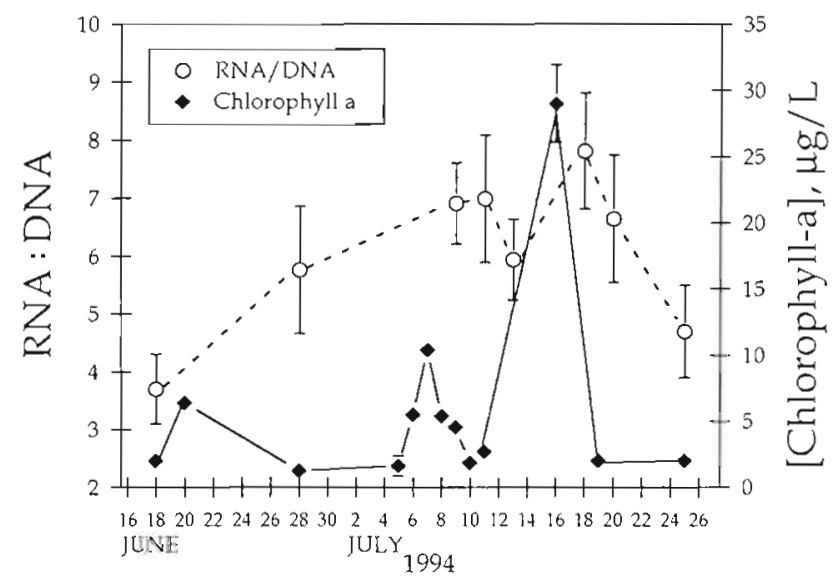

Fig. 2. Mytllus californianus. Changes in RNA:DNA ratio of mussels and chl a concentrations during coastal upwelling at Strawberry Hill. Data points are means $( \pm 1 \mathrm{SE}$ ) of values for 10 individuals. $p<0.050$ for a 1-way ANOVA of RNA:DNA ratio between mussels collected on that day and on 18 June 1994 , before coastal upwelling began. Concentrations of chl a are in $\mu l \mathrm{l}^{-1}( \pm \mathrm{SD})$ of seawater $(\mathrm{n}=5)$ collected at waveexposed sites at $\mathrm{SH}$ on those days chl a resulted in significant increases in mussel RNA:DNA ratio.

\section{Metabolic activity: differences between sites}

Metabolic activity of Mytilus californianus, as indexed by enzyme activities of gill and adductor muscle, differed with site and exposure by season [Table 2 : Site $\times$ Exposure $\times$ Time interactions were significant for citrate synthase (CS) and malate dehydrogenase $(\mathrm{MDH})$ in multivariate and univariate analyses]. Some of these differences are illustrated in Fig. 3. MDH activity of adductor muscle (Fig. 3A) was higher for mussels from wave-exposed areas at $\mathrm{SH}$ than at $\mathrm{BB}$ in both April and July 1993 and April 1994. CS activity of gill (Fig. 3B) was higher for SH mussels in April 1993 and February, April, and July 1994. While differences in metabolic activity between mussels at $\mathrm{SH}$ and $\mathrm{BB}$ were less pronounced in fall and winter, clear seasonal patterns in these indices were not evident (Fig. 3). Instead, $\mathrm{CS}$ and $\mathrm{MDH}$ at $\mathrm{SH}$ tended to remain rela- and July 1993 and February and July 1994; values for other times were not different (Fig. 1B; p values for 1-way ANOVA shown). Exposure differences were time-dependent (Exposure $\times$ Time interaction is significant; Table 1). Therefore, during much of the year, but especially during the summer months, mussels in waveexposed areas had higher RNA:DNA ratios than did individuals in waveprotected areas.

\section{RNA:DNA ratio: rapid response during coastal upwelling}

RNA:DNA ratios of adductor muscle for Mytilus californianus from waveexposed areas at $\mathrm{SH}$ were significantly higher than those for mussels collected on 18 June, 2 to 8 d after rapid increases in chl a concentrations ( 7 July and 16 July) (p-values for 1-way ANOVA are shown in Fig. 2), RNA: DNA ratios returned to 'baseline' levels within 4 to $8 \mathrm{~d}$ after a drop in chl a concentrations (Fig. 2). The increase in RNA:DNA ratio was correlated with increases in chl a at least 3 times in 1994, although not all increases in
Table 2. ANOVA and MANOVA of the effect of site, exposure, and time on the enzymatic activity of Mytulus californianus. Site, exposure and time: as in Table 1. ns: $p>0.050$

\begin{tabular}{|c|c|c|c|c|}
\hline ANOVA & $d f$ & MS & $F$ & $p$ \\
\hline \multicolumn{5}{|l|}{ CS activity } \\
\hline Site & 1 & 0.518 & 3.716 & ns \\
\hline Exposure & 1 & 0.217 & 1.553 & ns \\
\hline Time & 5 & 2.577 & 18.48 & $<0.0005$ \\
\hline Site $\times$ Exposure & 1 & 0.556 & 3.990 & 0.0470 \\
\hline Site $\times$ Time & 5 & 0.322 & 2.378 & 0.0400 \\
\hline Exposure $\times$ Time & 5 & 1.889 & 13.55 & $<0.0005$ \\
\hline Site $\times$ Exposure $\times$ Time & 5 & 0.434 & 3.111 & 0.0100 \\
\hline Error & 186 & 0.139 & & \\
\hline \multicolumn{5}{|l|}{ MDH activity } \\
\hline Site & 1 & 8194.7 & 63.89 & $<0.0005$ \\
\hline Exposure & 1 & 10258 & 79.98 & $<0.0005$ \\
\hline Time & 5 & 1448.7 & 11.29 & $<0.0005$ \\
\hline Site $\times$ Exposure & 1 & 63.84 & 0.498 & ns \\
\hline Site $\times$ Time & 5 & 1390.6 & 10.84 & $<0.0005$ \\
\hline Exposure $\times$ Time & 5 & 751.48 & 5.859 & $<0.0005$ \\
\hline Site $\times$ Exposure $\times$ Time & 5 & 1017.5 & 7.932 & $<0.0005$ \\
\hline Error & 186 & 128.27 & & \\
\hline \multicolumn{5}{|l|}{ MANOVA } \\
\hline Source of variation & $d f$ & Wilks' lambda & $F$ & $\mathrm{p}$ \\
\hline Site & 2185 & 0.7344 & 33.45 & $<0.00005$ \\
\hline Exposure & 2185 & 0.6959 & 40.42 & $<0.00005$ \\
\hline Time & 10370 & 0.5150 & 14.56 & $<0.00005$ \\
\hline Site $\times$ Exposure & 2185 & 0.9766 & 2.216 & ns \\
\hline Site $\times$ Time & 10370 & 0.7332 & 6.209 & $<0.00005$ \\
\hline Exposure $\times$ Time & 10370 & 0.6525 & 8.805 & $<0.00005$ \\
\hline Site $\times$ Exposure $\times$ Time & 10370 & 0.7610 & 5.413 & $<0.00005$ \\
\hline
\end{tabular}



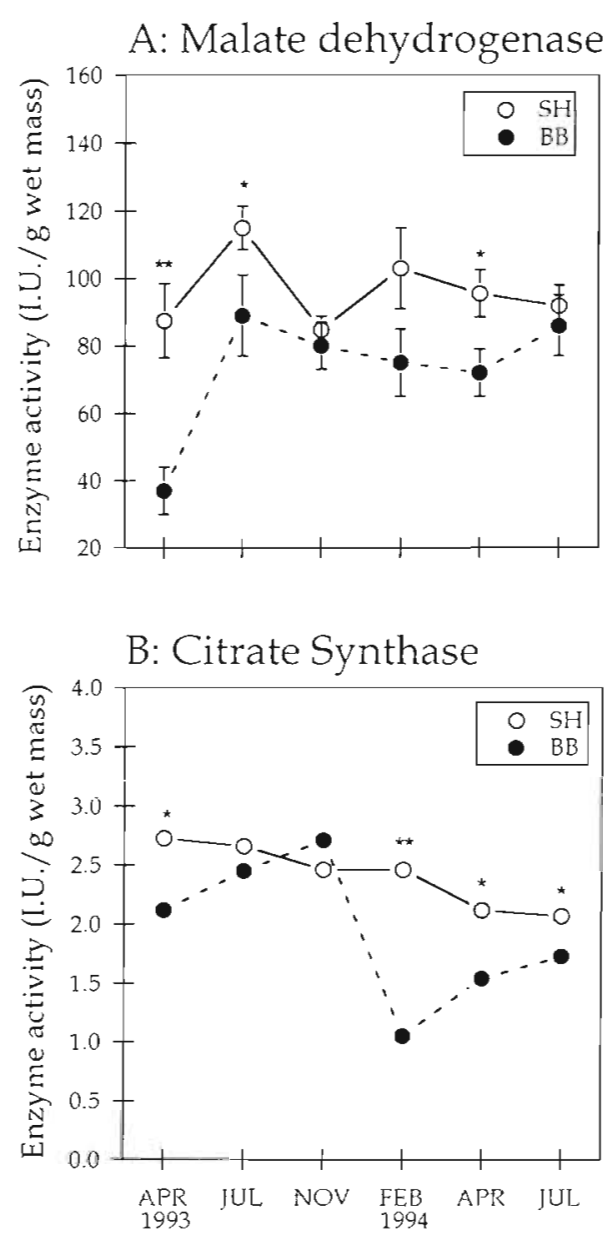

Fig. 3. Mytilus californianus. Changes in (A) adductor muscle malate dehydrogenase and (B) gill citrate synthase activities of mussels from wave-exposed areas at Strawberry Hill (SH) and Boiler Bay (BB). Data points are means $( \pm 1 \mathrm{SE})$ of 10 individuals collected $90 \mathrm{~d}$ apart. Asterisks indicate significance of comparison between sites by date $(" p<0.05, \cdots p<0.01)$.

Additional statisitcal analysis of these data in Table 2

tively constant, while values for animals at $\mathrm{BB}$ tended to fluctuate. No differences were observed in enzymatic activities for mussels at wave-protected sites (data not shown).

\section{Biochemical variation under experimental conditions: mussel transplants}

The mussel transplant experiments tested the hypothesis that differences in mussel physiology were influenced by environmental factors (see 'Materials and methods'). Prior to transplantation in May 1994, RNA:DNA ratios of adductor muscle of mussels at $\mathrm{SH}$ were higher than those of mussels at BB (Fig. 4; 1 -way ANOVA, $p<0.0001)$. After transplantation,
RNA:DNA ratios of mussels transplanted between sites (wave-exposed only) changed rapidly (Fig. 4). Within 4 wk (June), RNA:DNA ratios of mussels transplanted from $\mathrm{BB}$ to $\mathrm{SH}$ (between-site transplants) were indistinguishable from those of mussels transplanted from SH back to $\mathrm{SH}$ (SH controls), and were significantly different from RNA:DNA ratios of mussels from the site of origin, the $B B$ controls (June; Fig. 4, Table 3; 1-way ANOVAs). Similarly, RNA:DNA ratios of mussels transplanted from $\mathrm{SH}$ to $\mathrm{BB}$ were indistinguishable from $\mathrm{BB}$ control mussels within 8 wk (July; Fig. 4, Table 3). These differences persisted through August, after which RNA:DNA ratios for between-site transplants inexplicably converged, as did those for within-site transplants (October; Fig. 4).

The effects of wave exposure on RNA:DNA ratios of transplanted mussels was much smaller than effects of site (Fig. 5). Repeated-measures analysis indicated that there was no significant effect of exposure transplant over time at either SH or BB, except for August 1994 at SH ( $p>0.050$ for all cases except August). In August at SH, RNA:DNA ratios of mussels transplanted from exposed to protected areas were significantly lower than RNA:DNA ratios of exposed transplant control mussels and indistinguishable from those of protected transplant control mussels (1-way ANOVA, $p<0.0001)$. Similarly, RNA:DNA ratios of protected to exposed mussels were significantly higher than those of protected transplant control mussels, and were indistinct from RNA:DNA ratios of exposed transplant control mussels (Fig. 5A; 1-way ANOVA, $\mathrm{p}<0.0001$ )

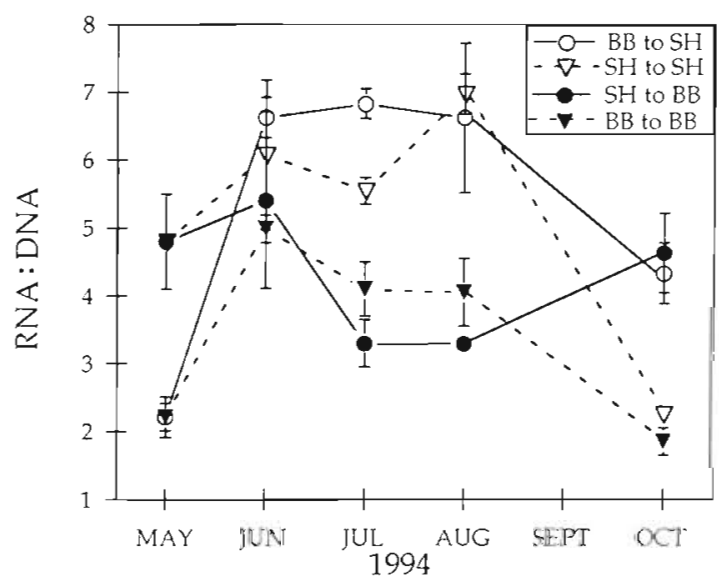

Fig. 4. Mytilus californianus. Changes in RNA:DNA ratios of mussels transplanted between wave-exposed areas at $\mathrm{SH}$ and $B B$. Data points are means ( $\pm 1 \mathrm{SE}$ ) of values for 12 indıviduals, obtained by combining 3 mussels from each of 4 cages for each time point. Statistical analysis of these data shown in Table 3 


\section{DISCUSSION}

The primary objective of this study was to evaluate the extent to which nearshore primary productivity $(\mathrm{PP})$ is linked to the nutritional status of a species central to the dynamics of many rocky intertidal communities, the suspension-feeding bivalve Mytilus californianus. Given its ecological importance isee references in 'Introduction'), the demonstration of variation in physiological status associated with differences in environmental conditions provides insight into the ecological role played by this species. The results reported in this paper suggest a strong link between nearshore food availability and mussel physiology (as reflected by indices of protein synthetic capacity and metabolic activity) that was dependent on site, wave exposure, and time. Our results also suggest that mussels have a high degree of physiological plasticity in response to variation in environmental conditions, and that changes in mussel physiology can occur rapidly in response to variation in nearshore PP.

\section{Site effects}

Previous ecological studies have demonstrated that SH and BB differ in several respects: (1) abundance of macrophytes, sessile suspension feeders, and mobile invertebrate consumers; (2) predation intensity ( $\mathrm{SH}>$ $\mathrm{BB})$; and, most relevant to the present investigation; (3) growth rates of mussels and barnacles $(\mathrm{SH}>\mathrm{BB}$; Menge 1992, Menge et al. 1994). Previous studies have also shown that chl a concentrations are higher at $\mathrm{SH}$ than at BB for most of the year and are especially pronounced during periods of coastal upwelling (Menge et al. 1995, 1996). The results of the present study are consistent with, and offer further insight into, these ecological results: (1) mussels from SH had higher RNA:DNA ratios and enzyme activities than mussels from BB in July 1993 and 1994 (Figs. 1 \& 3); (2) the time-course of 'activation' of this accelerated growth potential in response to an increase in food availability with coastal upwelling may be on the order of days, as mussels at $\mathrm{SH}$ showed significantly elevated RNA:DNA ratios within 2 to $6 \mathrm{~d}$ after peaks in chl $a_{\text {, }}$

Table 3. Effects of site (SH and BB) by time after transplant on RNA:DNA ratios of transplanted mussels. Sampling protocols described in 'Materials and methods' $d f=1$ for all cases. All SH versus BB comparisons were done for wave-exposed mussels only. Significant $F$-values are in bold ( $p<0.05, \cdots p<0.01, \cdots p<0.001)$. ns: $p>0.050$

\begin{tabular}{|c|c|c|c|c|c|c|}
\hline \multicolumn{7}{|c|}{ A. One-way ANOVA } \\
\hline \multirow[t]{2}{*}{ Treatment } & \multirow[t]{2}{*}{ Control } & \multirow[t]{2}{*}{ Statistic } & \multicolumn{4}{|c|}{ Weeks after transplant } \\
\hline & & & 4 (Jun) & $8(\mathrm{Jul})$ & $12(\mathrm{Aug})$ & $20(O c t)$ \\
\hline \multirow[t]{2}{*}{$\mathrm{SH}$ to $\mathrm{BB}$} & $\mathrm{SH}$ & MS & 3.726 & 10.06 & 13.29 & 11.38 \\
\hline & & $F$ & 1.945 & $28.48^{* *}$ & $88.33 \cdots *$ & $15.47^{\circ}$ \\
\hline \multirow[t]{2}{*}{$\mathrm{BB}$ to $\mathrm{SH}$} & $\mathrm{BB}$ & MS & 4.819 & 4.103 & 11.21 & 11.65 \\
\hline & & $F$ & $13.19^{\cdots}$ & $10.12^{* *}$ & $6.492^{\circ}$ & $20.17^{\cdots}$ \\
\hline \multirow[t]{2}{*}{$\mathrm{SH}$ to $\mathrm{BB}$} & $\mathrm{BB}$ & MS & 0.373 & 0.854 & $3.420^{\mathrm{a}}$ & 14.53 \\
\hline & & $F$ & 0.085 & 1.086 & $22.90^{\circ}$ & $15.61^{\circ}$ \\
\hline \multirow[t]{2}{*}{$\mathrm{BB}$ to $\mathrm{SH}$} & SH & MS & 3.618 & 0.000 & 0.673 & $8.653^{\circ}$ \\
\hline & & $F$ & 3.068 & 0.000 & 0.634 & 19.63 \\
\hline \multicolumn{7}{|c|}{ B. Repeated-measures analysis } \\
\hline Treatment & Control & Wilks' lambda & MS & $F$ & $\mathrm{p}$ & \\
\hline \multicolumn{7}{|c|}{ Univariate repeated-measures analysis } \\
\hline $\mathrm{SH}$ to $\mathrm{BB}$ & $\mathrm{SH}$ & & 21.467 & 5.451 & 0.0021 & \\
\hline $\mathrm{BB}$ to $\mathrm{SH}$ & BB & & 18.61 & 5.733 & 0.0018 & \\
\hline $\mathrm{SH}$ to $\mathrm{BB}$ & BB & & 0.672 & 0.142 & ns & \\
\hline $\mathrm{BB}$ to $\mathrm{SH}$ & $\mathrm{SH}$ & & 3.856 & 0.750 & ns & \\
\hline \multicolumn{7}{|c|}{ Multivariate repeated-measures analysis } \\
\hline $\mathrm{SH}$ to $\mathrm{BB}$ & $\mathrm{SH}$ & 0.3911 & & 10.38 & 0.0002 & \\
\hline $\mathrm{BB}$ to $\mathrm{SH}$ & BB & 0.3655 & & 9.258 & 0.0009 & \\
\hline $\mathrm{SH}$ to $\mathrm{BB}$ & $\mathrm{BB}$ & 0.9525 & & 0.2659 & ns & \\
\hline $\mathrm{BB}$ to $\mathrm{SH}$ & $\mathrm{SH}$ & 0.9160 & & 0.613 & ns & \\
\hline
\end{tabular}



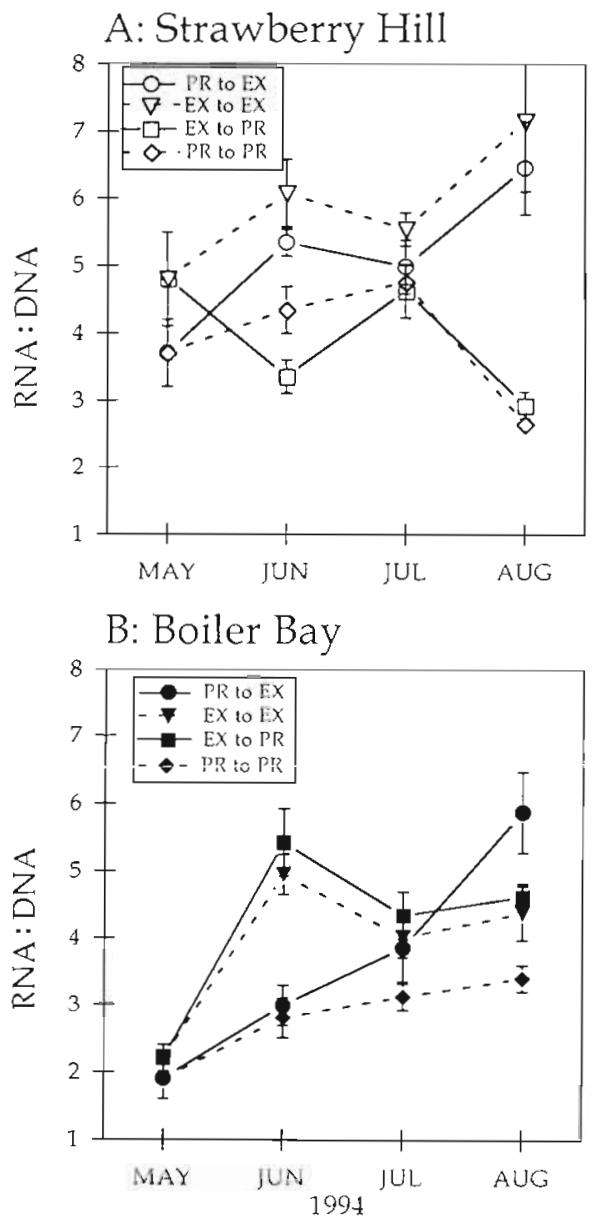

Fig. 5. Mytilus californanus. Changes in RNA:DNA ratios of mussels transplanted between wave-exposed and waveprotected areas at (A) SH and (B) BB. Data derived as for Fig. 4

and RNA:DNA ratios decreased after chl a levels dropped to pre-upwelling values (Fig 2); (3) RNA:DNA ratios of transplanted mussels were indistinguishable from those of nearby control mussels and were significantly different from those of control mussels at the site of origin within 4 to $8 \mathrm{wk}$ of transplantation, depending on site of origin and transplant treatment (Fig 4, Table 3)

These data suggest that mussels may be highly acclimatable in response to site-related differences in nearshore PP. This high degree of physiological plasticity may have significant ramifications for community structure. Mussels are a major ecological player in wave-swept intertidal communities. Given that PP is different between BB and $\mathrm{SH}$ (Menge et al. 1995), and that $\mathrm{SH}$ is dominated by suspension-feeding invertebrates (Menge et al. 1994), the observation that mussels respond rapidly to changes in nearshore PP supports the hypothesis that 'bottom-up' effects may be an important determinant of differences in community structure between $\mathrm{BB}$ and $\mathrm{SH}$. While such a mechanistic link between environmental conditions and ecological performance is still untested, the observation that the physiological status of a major competitive dominant in the wave-swept rocky intertidal region appears to be linked to site-and exposure-related differences in nearshore food availability suggests one mechanism by which community structure may be influenced by environmental gradients in food availability.

Differences between $\mathrm{SH}$ and $\mathrm{BB}$ had a strong seasonal component; that is, the highly significant effects of site on differences between RNA:DNA ratio and enzyme activities are time-dependent (Tables $1 \& 2$ ). Seasonal effects are illustrated by the observation that mussels collected in July 1993 and 1994 had higher RNA:DNA ratios and enzyme activities than mussels collected in November 1993 or February 1994 (Figs. 1 \& 3, Tahles 1 \& 2). Not surprisingly, chl a concentrations have been higher in summer (June to August) than in winter (November to February) each year from 1992 to 1996 (Menge et al. 1995, 1996, 1997). During times of low productivity (November to February), chl $a$ and nutrient concentrations were slightly higher at $\mathrm{SH}$ than BB. During times of high productivity (June to August), the differences between site were much greater, with chl a concentrations up to 5 -fold higher at $\mathrm{SH}$ than at BB (e.g. Menge et al. 1995, 1996). The observation that differences in the physiology of suspension-feeding mussels at $\mathrm{BB}$ and $\mathrm{SH}$ are most pronounced during periods of upwelling and high productivity, and are weak or non-existent during times of low productivity, supports the hypothesis that there is a link between nearshore productivity and mussel physiology.

Seasonal variation in the quantity of food available is likely to have strong effects on mussel physiology, as our data suggest. However, seasonal and spatial variation in the composition of phytoplankton and the availability of other food sources can influence mussel physiology as well, as illustrated by the following examples. (1) There is a relationship between composition of the diet and metabolic activity of mussels (Hawkins \& Bayne 1992, Kreeger 1993, Kreeger \& Langdon 1993. Fidalgo et al. 1994). For example, Mytilus galloprovinciallis and $M$. trossulus fed phytoplankton with high protein content had significantly higher growth rates than conspecifics fed low protein phytoplankton (Kreeger \& Langdon 1993, Fidalgo et al. 1994). (2) Mussels can adjust metabolism depending upon the composition of their diet (Hawkins \& Bayne 1992). (3) Mussels have additional food sources besides phytoplankton, such as detritus and dissolved organic matter, and mussels may utilize these sources during times of low PP (Manahan 1990, Bayne \& Hawkins 
1990). (4) Mussels may alter feeding behavior significantly in response to variation in diet (Willows 1985, Bayne et al. 1993, Sanford et al. 1994). For example, $M$. edulis that were fed on diets low in organic content increased both feeding rate and absorption efficiency relative to individuals fed on a high organic content diet (Bayne et al. 1993). These examples illustrate the fact the composition of the diet, as well as feeding behavior, must be considered when discussing the effects of variation in food availability in situ. Because the composition of phytoplankton may be different at different sites, further studies of the links between nearshore productivity and the physiology of suspension-feeding invertebrates at these sites will be necessary to dissect differences caused by the composition versus the quantity of food

A major physiological factor that may differ between mussels at any given time or site is reproductive state. Some suspension feeders (most notably the mussel Mytilus edulis) show annual fluctuations in gonad development and spawning in response to a number of factors, including variation in food availability, and gonad development can affect RNA:DNA ratio of tissues (Seed 1975, Robbins et al. 1990, Seed \& Suchanek 1992). However, variation in gonad development was probably not a confounding factor in this study. Gonad development was monitored, and no significant differences in gonad production (as indexed by gonad mass $\mathrm{g}^{-1}$ total wet mass) were observed between $\mathrm{SH}$ and BB at any time of the year (data not shown). These observations are in agreement with studies which demonstrated that gonad development in $M$. californianus does not show the strong cyclicity that is observed in other species (Suchanek 1981. Seed \& Suchanek 1992). While there are factors that alter gonad production in $M$. californianus (notably disturbance), neither season nor site in the present study seemed to influence gonad production, so that differences in RNA:DNA ratio observed between $\mathrm{BB}$ and $\mathrm{SH}$ were likely due to other factors

\section{Wave exposure effects}

RNA:DNA ratios were higher for adductor muscle of mussels from wave-exposed areas than for conspecifics from wave-protected areas (Fig. 1). These significant effects of wave exposure on RNA:DNA ratio were observed for individuals from both SH and BB and were most pronounced during spring and summer, when differences in nearshore productivity, as well as potential differences in thermal stress, are greatest (Fig. 1, Table 1). Comparisons of mussels at the top (high-exposed) and bottom (low-exposed) of a waveexposed bed at SH showed no significant differences in RNA:DNA ratio or enzyme activities in July 1993 and 1994, so the effects of wave exposure on mussel physiology is probably more related to degree of wave exposure, rather than tidal height per se (data not shown). That is, high-exposed mussels get splashed almost as much as low-exposed mussels, and have lower body temperatures than wave-protected mussels (Roberts et al. in press). Changes in the RNA:DNA. ratios of adductor muscle of mussels transplanted between wave-exposed and wave-protected areas at $\mathrm{SH}$ and $\mathrm{BB}$ showed that wave-protected mussels had significantly lower RNA:DNA ratios in August, independent of site of origin. Mussel body temperatures preceding the August collection were high $\left(31^{\circ} \mathrm{C}\right)$ relative to June $\left(21^{\circ} \mathrm{C}\right)$ and July $\left(22^{\circ} \mathrm{C}\right)$ (authors unpubl. obs.). These observations implicate elevated temperatures as a major factor influencing differences in physiology for mussels living at different wave exposures.

Recent studies on mussels at $\mathrm{SH}$ show that differences in body temperature that result from differences in wave exposure are associated with differential expression of stress-inducible proteins, specifically heat-shock protein 70 (hsp-70) (Roberts et al. 1996). Mussels transplanted to wave-protected areas had significantly higher concentrations of hsp-70 than those at wave-exposed areas (Hofmann \& Somero 1996, Roberts et al. in press). Also, the amount of thermally damaged protein, measured by the levels of ubiquitin conjugates in tissues of mussels from $\mathrm{SH}$, is greater for mussels living at wave-protected areas than for individuals at wave-exposed areas (Hofmann \& Somero 1996). The repair of thermally damaged proteins (using hsp-70 as a catalyst to facilitate re-folding of thermally damaged proteins) or removal of irreversibly damaged proteins from the total protein pool (via ubiquitination of damaged proteins and subsequent degradationj utilizes ATP that could be used for anabolic processes (cf. Lindquist 1986). Mussels living at waveprotected areas at $\mathrm{SH}$ and $\mathrm{BB}$ do grow more slowly and are smaller than those at wave-exposed areas (Menge et al. 1994). The observation that wave-protected mussels have lower RNA:DNA ratios than wave-exposed mussels may be because wave-protected mussels 'turn down' anabolic processes to compensate for energy used to repair thermally damaged proteins (Roberts et al. in press).

Another major factor that is likely to influence the physiological status of mussels living at distinct wave exposures is the amount of time available for mussels to feed. Previous studies have suggested that suspension feeders will experience greater delivery of food and greater feeding opportunities in wave-exposed areas due to high flow and greater 'splash' at waveexposed areas (Menge 1978a, b, 1983, Denny 1988, Bertness et al. 1991). The results of the present study 
suggest that, on average, wave-exposed mussels are making more new protein than wave-protected individuals. However, from these data it is impossible to distinguish physiological variation due to amount of time available for the mussels to suspension feed and the effects of elevated body temperatures.

We investigated the relationship between nearshore food availability and the physiology of the mussel Mytilus californianus to gain insight into mechanism(s) underlying variation in community structure between rocky intertidal regions experiencing differences in nearshore phytoplankton productivity. The data presented in this paper suggest a strong link between nearshore phytoplankton productivity and the physiology of a dominant suspension feeder, $M$. californianus, that is reflected by differences in site, season, and wave exposure. We therefore conclude that the examination of the metabolic activity of ecologically important spccics can provide valuable insight when examining links between nearshore oceanic processes and rocky intertidal community structure.

Acknowledgements. We thank J. Podrabsky, L. Tomanek, T Mulch, A. Ambrosier and especially B. Buckley and B. Daley for their invaluable assistance in the field and laboratory. We thank S. Navarrete for his critical assistance in the statistical analysis of these data and J. Stillman and the Lubmengo laboratory group for critical review of the manuscript. Finally, we especially acknowledge G. Somero for his intellectual contribution to, and his generous laboratory support of, this project. This research was funded in part by an Andrew Mellon Foundation grant to B.A.M. and $J$ Lubchenco (1992-1995), an NSF grant (OCE92-17459) and a John Simon Guggenheim Fellowship to B.A.M.

\section{LITERATURE CITED}

Bayne BL, Hawkins AJS (1990) Filter-feeding in bivalve molluscs: controls on enery balance. In: Mellinger $J$ (ed) Animal nutrition and transport processes, Vol 1. Nutrition in wild and domestic animals. Karger, Basel, p 70-83

Bayne BL, Iglesias JP, Hawkins A.J. Navarro E, Heral M. Deslous-Paolu MJ (1993) Feeding behaviour of the mussel, Mytilus eduls: responses to variations in the quantity and organic content of the seston. J Mar Biol Ass UK 73(4) 813-829

Bayne BL, Widdows J (1978) The physiological ecology of two populations of Myt1lus edulis L. Uecologia 37:137-162

Bentle LA, Dutta S, Metcoff J (1981) The sequential enzymatic determination of DNA and RNA. Analyt Brochem 116:5-16

Bertness MD, Gaines SD, Bermudez D, Sanford ES (1991) Extreme spatial variation in the growth and reproductive output of the acom barnacle Semibalanus balanoides. Mar Ecol Prog Ser 75:91-100

Buckley LJ (1984) RNA-DNA ratio: an index of larval fish growth in the sea. Mar B1ol 80:291-298

Carpenter SR (ed) (1988) Complex interactions in lake communities. Springer-Verlag, New York
Connell JH (1961a) The influence of interspecific competition and other factors on the distribution of the barnacle Chthamalus stellatus. Ecology 42:710-723

Connell JH (1961b) Effects of competition, predation by Thats lapillus, and other factors on natural populations of the barnacle Balanus balanoides. Ecol Monogr 31:61-104

Dahlhoff EP, Menge BA (1996) Physiological effects of starvation and thermal stress on an important rocky intertidal predator: implications for consumer stress models. Bull Ecol Soc. Am 77:100

Dayton PK (1971) Competition, disturbance, and community organization: the provision and subsequent utilization of space in a rocky intertidal community. Ecol Monogr 41 $351-389$

Denny MW (1988) Biology and the mechanics of the waveswept environment. Princeton Univ Press, Princeton, NJ

Fidalgo JP, Cid A, Lopez MI, Abalde J, Herrero C (1994) Growth and biochemical profile of juvenile mussels (Mytilus galloprovincialis Lmk) fed on different algal diets. J Shellfish Res 13(1):67-75

Foster AR, Houlihan DF, Hall SJ (1993) Effects of nutritional regime on correlates of growth rate in juvenile Atlantic cod Gadus morua: comparison of morphological and biochemical measurements. Can J Fish Aquat Sci 50:502-512

Fretwell SD (1987) Food chain dynamics: the central theory of ecology? Oikos 50:291-301

Hawkins AJS, Bayne BL (1984) Seasonal variation in the balance between physiological mechanisms of feeding and digestion in Mytilus edulis (Bivalvia: Mollusca). Mar Biol 82:233-240

Hawkins AJS, Bayne BL (1992) Physiological interrelations, and the regulation of production. In: Gosling $E$ (ed) Developments in aquaculture and fisheries science, Vol 25. The mussel Mytilus: ecology, physiology, genetics and culture. Elsevier, Amsterdam, p 171-222

Hochachka PW. Somero GN (1984) Biochemical adaptation. Princeton Unıv Press, Princeton, NJ

Hofmann GE, Somero GN (1995) Evidence for protein damage at environmental temperatures: seasonal changes in levels of ubiquitin conjugates and hsp 70 in the intertidal mussel Mytilus trossulus. J Exp Biol 198:1509-1518

Hofmann GE, Somero GN (1996) Comparison of ubiquitin conjugate levels in the mussel Mytilus californianus from different tidal heights in the rocky intertidal. Mol Mar Biol Biotechnol (in press)

Kreeger DA (1993) Seasonal patterns in utilization of dietary protein by the mussel Mytılus trossulus. Mar Ecol Prog Ser 95(3):215-232

Kreeger DA, Hawkıns AJS, Bayne BL, Lowe DM (1995) Seasonal variation in the relative utilization of dietary protein for energy and biosynthesis by the mussel Mytilus edulis. Mar Ecol Prog Ser 126:177-184

Kreeger DA, Langdon CJ (1993) Effect of dietary protein content on the growth of juvenile mussels, Mytilus trossulus. Biol Bull Mar Biol Lab, Woods Hole 185(1):123-139

Kreeger KE, Kreeger DA, Langdon CJ, Lowry RR (1991) The nutntional value of Artemia and Tigriopus californicus (Bala) for two Pacific mystıd species, Metamystidopsis elongata (Holmes) and Mystidopsis intii (Holmquist). J Exp Mar Biol Ecol 148:147-158

Lindquist S (1986) The heat-shock response. A Rev Biochem 55:1151-1191

Lubchenco J (1978) Plant species diversity in a manne intertidal community: importance of herbivore food preferences and algal competitive abilitites. Am Nat 112:23-29

Manahan DT (1990) Adaptations by invertebrate larvae for nutrent acquisition from seawater. Am Zool 30:147-160 
Martinez G, Torres M, Uribe E, Diaz MA, Perez H (1992) Biochemical composition of broodstock and early juvenile Chilean scallops, Argopecten purpuratus Lamarck, held in two different environments. J Shellfish Res 11(2):307-313

McQueen DJ, Johannes MRS, Post JR, Stewart TJ, Lean DRS (1989) Bottom-up and top-down impacts on freshwater pelagic community structure. Ecol Monogr 59:289-309

Menge BA (1978a) Predation intensity in a rocky intertidal community: relation between predator foraging activity and environmental harshness. Oecologia 34:1-16

Menge BA (1978b) Predation intensity in a rocky intertidal community: effect of an algal canopy, wave action and desiccation on predator feeding rates. Oecologia 34:17-35

Menge BA (1983) Components of predation intensity in the low zone of the New England rocky intertidal region. Oecologia 58:141-155

Menge BA (1991) Relative importance of recruitment and other causes of variation in rocky intertidal community structure. J Exp Mar Biol Ecol 146:69-100

Menge BA (1992) Community regulation: under what conditions are bottom-up factors important on rocky shores? Ecology 73:755-765

Menge BA, Berlow EL, Blanchette CA, Navarette SA, Yamada SB (1994) The keystone species concept: variation in interaction strength in a rocky intertidal habitat. Ecol Monog 64(3):249-286

Menge BA, Daley B, Wheeler PA (1995) Control of interaction strength in marine benthic communities. In: Polis G, Winemiller $\mathrm{KO}$ (eds) Food webs: integration of patterns and dynamics. Chapman \& Hall, New York, p 258-274

Menge BA, Daley B, Wheeler PA, Dahlhoff EP, Sanford ES, Strub PT (1997) Benthic-pelagic links and rocky intertidal communities: evidence for bottom-up effects on top-down control. Proc Natl Acad Sci USA (in press)

Menge BA, Daley B, Wheeler PA, Strub PT (1996) Rocky intertidal oceanography: an association between community structure and nearshore phytoplankton concentration. Limnol Oceanogr (in press)

Menge BA, Farrell TM (1989) Community structure and interaction webs in shallow marine hard-bottom communities: tests of an environmental stress model. Adv Ecol Res $18: 189-262$

Menge BA, Olson AM (1990) Role of scale and environmental factors in regulation of community structure. Trends Ecol Evol 5:52-57

Menge BA, Sutherland JP (1987) Community regulation: variation in disturbance, competition, and predation in relation to environmental stress and recruitment. Am Nat 130:730-757

Navarette SA, Menge BA (1996) Keystone predation and interaction strength: interactive effects of predators on their main prey. Ecology (in press)

Navarro JM, Winter JE (1982) Ingestion rate, assimilation efficeincy and energy balance in Mytilus chilensis in relation to body size and different algal concentrations. Mar Biol $67: 255-266$

Newell RC (1979) Biology of intertidal animals. Marine Ecological Surveys, Ltd, Kent

Oksanen L. Fretwell SD, Arruda J, Niemala P (1981) Exploitation ecosystems in gradients of primary productivity. Am Nat 118:240-261

Paine RT (1966) Food web complexity and species diversity Am Nat 100:65-75
Paine RT (1974) Intertidal community structure: experimental studies on the relationship between a dominant competitor and its principal predator. Oecologia 15:93-120

Paine RT (1977) Controlled manipulations in the marine intertidal zone, and their contributions to ecological theory Academy of Natural Sciences, Philadelphia, Spec Publ 12 $245-270$

Paine RT (1984) Ecological determinism in the competition for space. Ecology 65:1339-1357

Robbins I, Lubet P, Besnard JY (1990) Seasonal variations in the nucleic acid content and RNA:DNA ratio of the gonad of the scallop Pecten maxımus. Mar Biol 105:191-195

Roberts DA, Hofmann GE, Somero GN (in press) Heat-shock protein expression in Mytilus californianus: acclimitization (seasonal and tidal height comparisons) and acclimation effects. Biol Bull (in press)

Sanford E, Bermudez D, Bertess MD, Gaines SD (1994) Flow food supply and acorn barnacle population dynamics. Mar Ecol Prog Ser 104:49-62

Seed R (1975) Reproduction in Mytilus edulis L. (Mollusca Bivalvia) in European waters. Pubbl Stn Zool Napoli 39 $317-334$

Seed R, Suchanek TH (1992) Population and community ecology of Mytilus. ln: Gosling $E$ (ed) Developments in aquaculture and fisheries science, Vol 25. The mussel Mytilus ecology, physiology, genetics and culture. Elsevier, Amsterdam, p 87-170

Stickle WB, Bayne BL (1987) Energetics of the muricid gastropod Thais (Nucella) lapillus (L.). J Exp Mar Biol Ecol 107 263-278

Stickle WB, Moore MN, Bayne BL (1985) Effects of temperature, salinity, predation and lysosomal stability of the dogwhelk Thals (Nucella) lapıllus (L.). J Exp Mar Biol Ecol 93 $235-258$

Stillman JH, Dahlhoff EP, Somero GN (1994) Biochemical indicators of physiological state in the intertidal mussel Mytilus californianus. Physiologist 37(5):921

Suchanek TH (1981) The role of disturbance in the evolution of life history strategies in the intertidal mussels Mytilus edulis and Mytilus californianus. Oecologia 50 $143-152$

Sullivan KM, Somero GN (1983) Size- and diet-related variations in enzymatic activity and tissue composition in the sable fish, Anoploma fimbria. Biol Bull Mar Biol Lab. Wools Hole 164:315-326

van Erkom Schurink C, Griffiths CL (1992) Physiological energetics of four South African mussel species in relation to body size, ration, and temperature. Comp Biochem Physiol 101A(4):779-789

Wilkınson L (1990) SYSTAT: the system for statistics. SYSTAT, Evanston, IL

Willows RI (1985) Optimal digestive investment: a model for suspension-feeders experiencing variable diets. Limnol Oceanogr 37:829-84?

Wright DA, Hetzel EW (1985) Use of RNA:DNA ratios as an indicator of nutritional stress in the Amencan oyster Crassostrea virginica. Mar Ecol Prog Ser 25:199-206

Yang TH, Somero GN (1993) Effects of feeding and food deprivation on oxygen consumption, muscle protein concentration, and activities of energy metabolism enzymes in muscle and brain of shallow- (Scorpaena guttata) and deep-(Sebastolobus alascanus) living Scorpaenid fishes J Exp Biol 181:213-23

Manuscript first received: February 2, 1996

Revised version accepted: August 30, 1996 